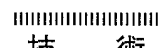
技術

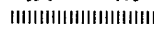

\title{
(4)
}

\section{蒸気温度 $593^{\circ} \mathrm{C} 1000 \mathrm{MW}$ タービンの開発・完成}

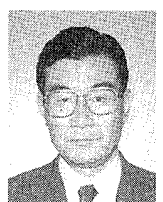

大野正道*1 (1940.8 生)

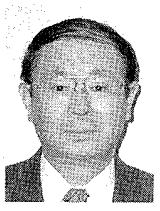

平井武夫*2 (1943.2 生)

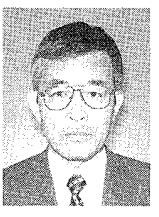

藤川卓 爾*3 (1944.11 生)
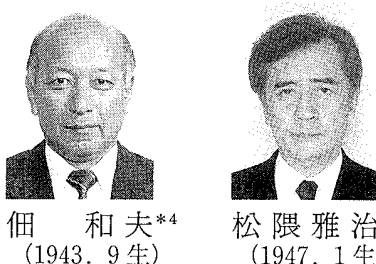

松隈 雅治*4 (1947. 1生)

\section{1. 概 要}

火力発電プラントを高温, 高圧化して効率向上をはかる超及 臨界压 (USC) 発電方式は, 埋蔵量の豊富な石炭を有効に利 用する方式の一つである. USC に必要なブレークスルーは温 度の壁の克服であるとの認識のもとに, 超高温に耐える材料と 構造を開発し，電源開発(株) の若松超高温タービン実証試験 によってこれを検証した。この成果を適用して，電源開発(株) 松浦 2 号向けに, 従来の超臨界圧プラントの蒸気温度を $593^{\circ} \mathrm{C}$ に向上した $1000 \mathrm{MW}$ タービンを開発・完成した.

\section{2. 技術の内容}

電源開発(株) 松浦 2 号 $1000 \mathrm{MW}$ タービンは蒸気条件 24.1 $\mathrm{MPa}, 593 / 593^{\circ} \mathrm{C}$ で, 容量では国内火力で最大, 蒸気温度では

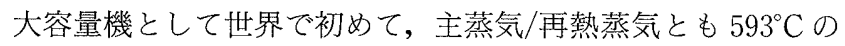
高温蒸気条件を達成した。蒸気条件の向上による効率向上に加 え, 国内火力タービンの低圧最終段翼としては最長である 46 インチ翼による排気損失低減，最終段翼も含めた反動段全段へ の完全三次元流れ設計インテグラルシュラウド翼採用による夕 ービン内部効率の向上をはかり, 従来の $24.1 \mathrm{MPa}, 538 /$ $566^{\circ} \mathrm{C}$ の $1000 \mathrm{MW}$ タービンに対し, 相対值で約 $3.3 \%$ の効率 向上を達成した.

松浦 2 号夕ービンの組立断面図を図 1 に，外観写真を図 2 に 示す. タービンは, 高圧, 中圧タービンをプライマリー軸, 二 つの低圧タービンをセカンダリー軸とするクロスコンパウンド 型である.

高圧，中压タービンでは，新 $12 \mathrm{Cr}$ 鉎鋼， $12 \mathrm{Cr}$ 鋳鋼， $9 \mathrm{Cr}$ 鍛鋼等のフェライト系の耐熱鋼を広範囲に使用した。高温部の

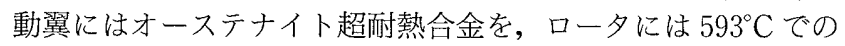
運転に十分なクリープ破断強度を持つ新 $12 \mathrm{Cr}$ 鍛鋼（TMK 1) を使用した。 TMK 1 は（1）低 C, (2) $1.5 \%$ Mo, (3) ESR 造

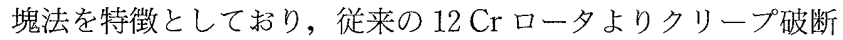
強度が高くなる。

高圧ロータ中央部は, 調速段ディスクに設けた冷却孔のポン ピング効果によって, 調速段出口の低温蒸気を複流ノズル室の 内周に導き，ノズル室中央に設けた穴から調速段出口部に循環 させることによって冷却する構造とした．また，3枚の動翼を 一つのブロックから放電加工で製作し，3本のピンでロータに 固定することによって振動強度, クリープ強度を向上する調速

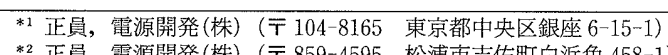

*2 正員, 電源開発 (株) (T 859-4595 松浦市志佐町白浜免 458-1)

*3 正員, 三菱重工業 (株)（兵 220-8401 横浜市西区みなとみらい3-3-1)

*4 正員, 三菱重工業 (株) (厂 676-8686 高砂市荒井町新浜 2-1-1)

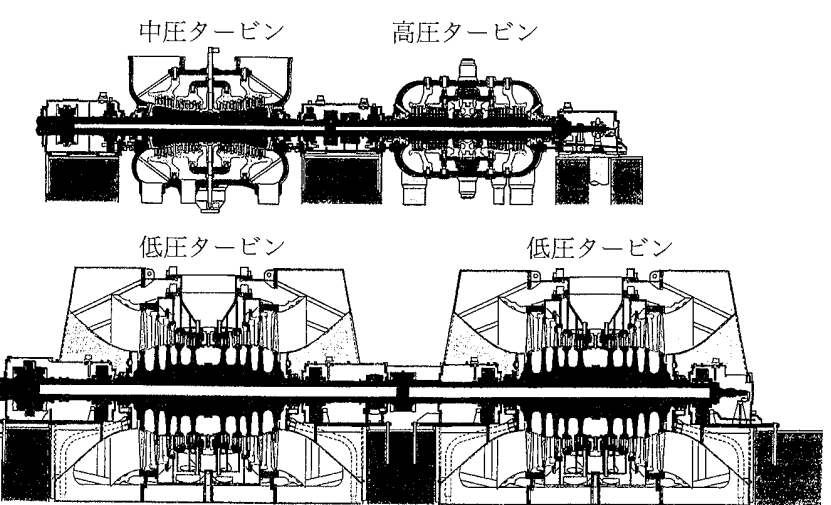

図 1 タービン組立断面図

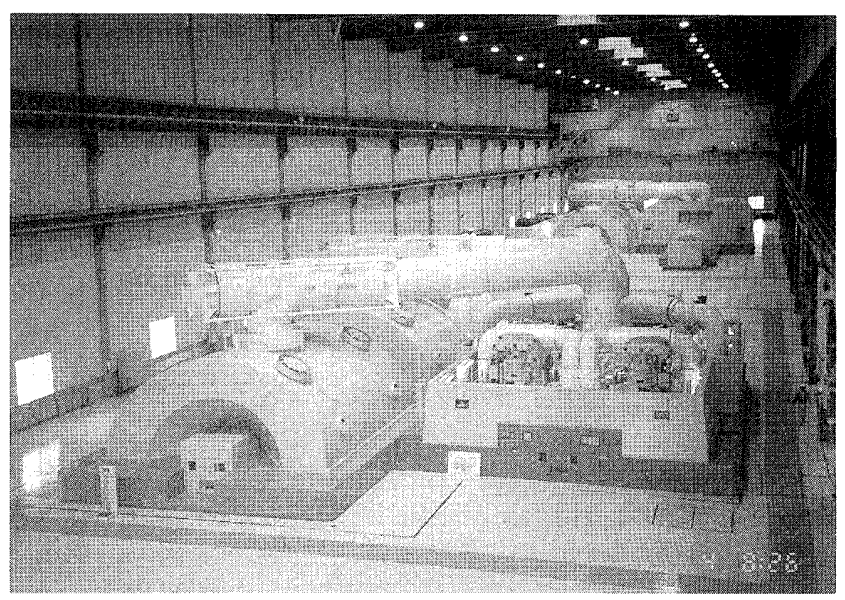

図 2 タービン外観写真

段トリプルピン動翼や，反動段インテグラルシュラウド翼な ぞ, 若松超高温タービンで開発し, 大容量商用機へ適用しなが ら確立してきた超高温タービン技術を採用した。

\section{3. ま と め}

電源開発(株) 松浦 2 号タービンは 1997 年 7 月運開, 1998 年の初回定検を経て, 高効率で順調に運転中である. 初回定検 でタービンを開放点検した結果, 各部に異常はなく, 蒸気温度 $593^{\circ} \mathrm{C}$ の $1000 \mathrm{MW}$ タービンの高性能, 高信頼性が確認され た。 